Portland State University

PDXScholar

1978

\title{
An investigation of similarity of the value system of the American and Japanese college students
}

Hiroyoshi Taguchi

Portland State University

Follow this and additional works at: https://pdxscholar.library.pdx.edu/open_access_etds

Part of the American Studies Commons, and the Japanese Studies Commons Let us know how access to this document benefits you.

Recommended Citation

Taguchi, Hiroyoshi, "An investigation of similarity of the value system of the American and Japanese college students" (1978). Dissertations and Theses. Paper 2839.

https://doi.org/10.15760/etd.2833

This Thesis is brought to you for free and open access. It has been accepted for inclusion in Dissertations and Theses by an authorized administrator of PDXScholar. Please contact us if we can make this document more accessible: pdxscholar@pdx.edu. 
AN ABSTRACT OF THE THESIS OF Hiroyoshi Taguchi for the Master of Arts in Speech Communication presented June 16, 1978 .

Title: An Investigation of Similarity of the Value system Between the American and Japanese College Students.

APPROVED BY MEMBERS OF THE THESIS COMMITTEE:

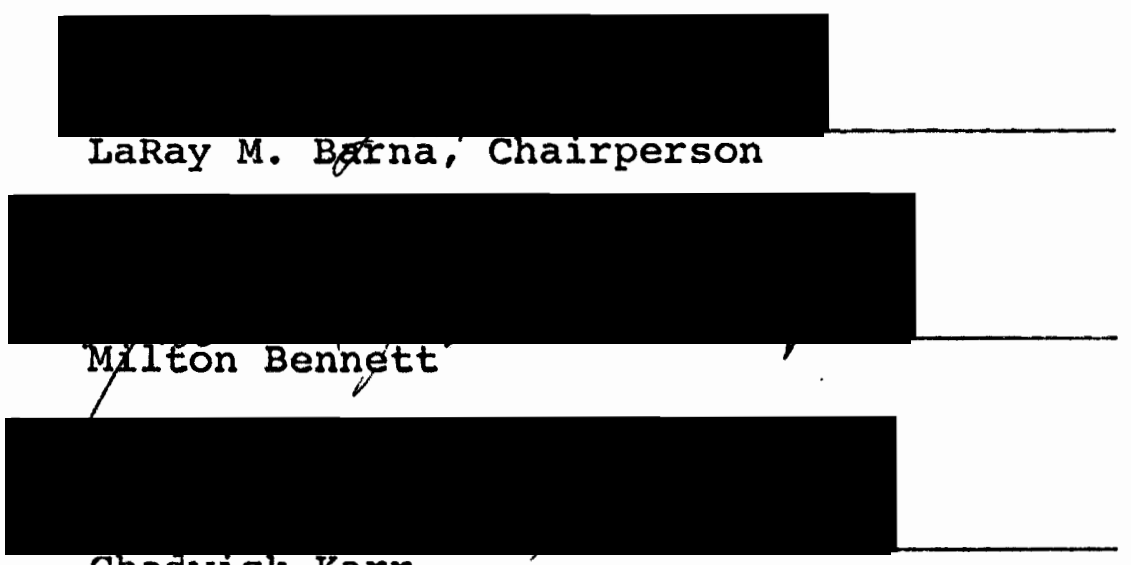

Chadwick Karr

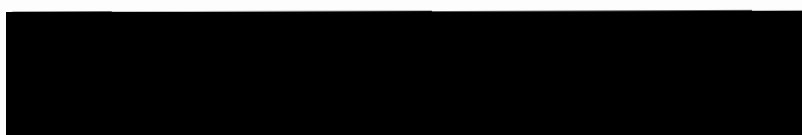

Daniel Scheans

The purpose of the present research was to investigate whether or not there is similarity of values between American and Japanese college students.

The following research hypothesis was established;

There is a positive relationship between the value system of the Japanese college students and that of American college students. 
To test the above research hypothesis, the following three null hypotheses were tested in the present research;

1) There is no similarity between the value system of the Japanese male college students and that of American male college students whose ages are between 18 and 22 .

2) There is no similarity between the value system of the Japanese female college students and that of American female college students whose ages are between 18 and 22 .

3) There is no similarity between the value system of the Japanese college students (male and female) and that of the American college students (male and female) whose ages are between 18 and 22 .

The value list which contained 15 American and Japanese values was administered to 219 Japanese college students at three universities in Tokyo and 115 American college students in Portland, Oregon.

The rank order correlation coefficient was computed for each null hypothesis and the orthogonal factor analysis was done on the Harris 220 at the Portland State University's computer center.

Correlation coefficient for the three null hypotheses showed a significantly positive relationship and as a result, all of the null hypotheses were rejected. Consequently, the research hypothesis of the present research was accepted. The American and Japanese college students showed a very similar value system despite their different cultural heritages. 
AN INVESTIGATION OF SIMILARITY OF THE VALUE SYSTEM OF THE AMERICAN AND JAPANESE COLLEGE STUDENTS

\author{
by \\ HIROYOSHI TAGUCHI
}

A thesis submitted in partial fulfillment of the requirement for the degree of

MASTER OF ARTS

in

SPEECH COMMUNICATION

Portland State University

1978 
TO THE OFFICE OF GRADUATE STUDIES AND RESEARCH:

The members of the Committe approve the thesis of Hiroyoshi Taguchi presented June 16, 1978.

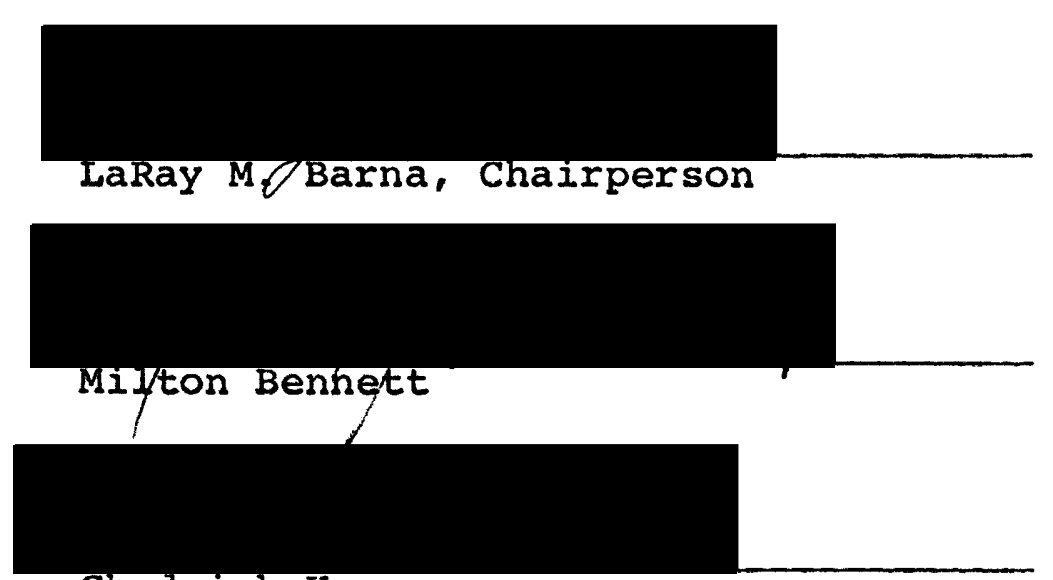

Chadwick Karr

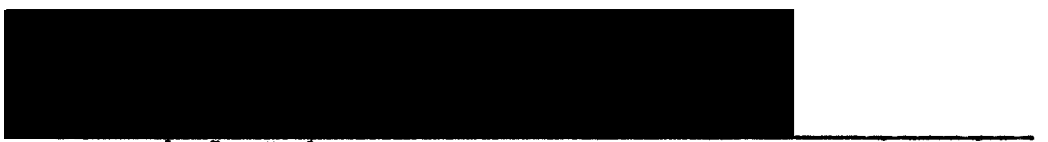

Daniel Scheans

APPROVED :

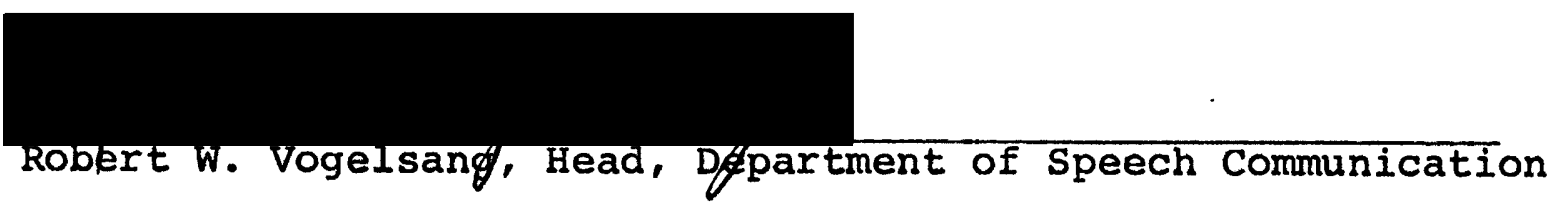




\section{ACKNOWLEDGMENTS}

My deepest and foremost gratitude is due to Professor LaRay Barna, my committee chairperson and adviser who has helped and guided me throughout the course of my study at Portland State University. Also a deepest appreciation is to be expressed to Dr. Milton Bennett and Dr. Daniel Scheans for their valuable suggestions. Dr. Chad Karr, Dr. Ted Grove and $\mathrm{Mr}$. Robert Kopp have been particularly of great help in the field of experimental design and postexperiment treatment.

I express my sincere thanks to Dr. Takehide Kawashima at Nippon University and Dr. Hakaru Itami at Dokkyo University and Dr. Roger Jennings at PSU for their cooperation in sampling, without which this research would not have been completed. My friends, Ms. Masako Sano and Susumu Tamba at the International Christian University deserve the same gratitude in the administration of the survey.

My friends at PSU, Jeff Sweeney, Debbie Sullivan, Liz Powell, Eiko Okumura, Katsu Shima, Kazuko Yone, Noriko Huruse, and Reiko Takeshige have not only helped me in conducting a survey, but also have been the best listeners and advisers for me since the beginning of my study at PSU.

Finally, I express my deepest love and gratitude to my wife, Ann, without whom I would not be what I am now. 
TABLE OF CONTENTS

PAGE

ACKNOWLEDGMENTS

LIST OF TABLES

CHAPTER

I INTRODUCTION . . . . . . . . . . . . 1

Background . . . . . . . . . 1

Purpose and Rationale of the Study

Justification . . . . . . . . .

II REVIEW OF THE LITERATURE . . . . . . . 12

General Definition of Values . . . 12

Review of Studies on Japanese

Culture and values . . . . .

Psychologists and

Psychiatrists

Anthropologists and

Sociologists

Intercultural Communication

Researchers

III METHOD AND SAMPLE . . . . . . . . . .

Method . . . . . . . . 28

Sample ............. . 41

IV RESULTS AND DISCUSSION

Hypothesis 1 . . . . . . . . . 46

Hypothesis 2 . . . . . . . . . . 49

Hypothesis 3 . . . . . . . 52 
CHAPTER

Within-Culture Analysis

Japanese Males and Females American Males and Females

Factor Analysis . . . . . . 57

$\mathrm{V}$ SUMMARY AND CONCLUSION . . . . . . . 63

BIBLIOGRAPHY . . . . . . . . . . . . 67

APPENDIX A . . . . . . . . . . . . . . 70

APPENDIX B . . . . . . . . . . . . . 71 


\section{LIST OF TABLES}

TABLE

PAGE

I Age Distribution--Japanese . . . . . . . 42

II Age Distribution--American . . . . . • 43

III Average Ranks and Differences--Male • . 48

IV Top Five Values with Their Average

$$
\text { Ranks-Male . . . . . . . . . . } 49
$$

V Average Ranks and Differences--Female • • 51

VI Top Five Values with Their Average

$$
\text { Ranks--Female • . . . . . . . . }
$$

VII Average Ranks and Differences--Male and Female . . . . . . . . . . 54

VIII Top Five Values with Their Average Ranks--Male and Female . . . . . . 55

IX Correlation Matrix--Japanese . . . . . . 59

X Correlation Matrix--American . . . . . . 60

XI Rotated Factor Matrix--Japanese . . . . 62

XII Rotated Factor Matrix--American . . . . 63 


\section{CHAPTER I}

\section{INTRODUCTION}

\section{Background}

Japan did not have contact with the U.S. in any form until 1853 when Commodore Perry led his "Black ships" to Shimoda. These Black ships were a shock to the Japanese in the last decade of the Edo period as they had never seen such modern vessels. Perry's ships also woke them up from a two-hundred-year-old sleep protected by Japan's isolation policy.

The Meiji restoration in 1868, following Perry's arrival, initiated the era of learning about the so-called advanced countries and "open door" trade policy. During this time the Meiji government dispatched many leaders and officials to Europe to learn everything they could, from the educational system to the military technology. Japan's transition from her feudal Samurai-ruled society to the highly industrialized society under democracy was initiated by the Meiji'government's efforts to learn "everything" from the West. At that time "the West" meant Europe, notably Britain, Germany, and France.

Japan succeeded in making herself into a more modern society during the period of Meiji and Taisho, but it was after W.W. II that Japan was transformed into a highly 
industrialized country with close ties with the West, and this time, with the United States in particular. W.W. II destroyed much of Japan's material assets, but since then she has built herself into one of the major economic powers under the strong influence of the U.S.

During the period of development and change in the Meiji, Taisho, and Showa eras, the Japanese people were exposed to Western culture and the Japanese government adopted many of the Western systems and much of the technology. The young Japanese, called "Sengo-ha" meaning "the generation after the war," were particularly affected by massive import of the Western culture.

In Japan there are two systems of three "generations" which are regarded as symbolizing three different characters or attitudes among the people. Under the first system, if a person was born before W.W. II, he belongs to "Senzen" (1iterally "before the war") generation. A person who was born during the war is from the "Senchu" ("during the war") generation, and the third generation is called "Sengo" which includes all the people born after the war. Another system is based on the Japanese calendar year (era), names of which have been changed over the years whenever a new emperor came to the throne. The period from 1868 to 1907 was called "Meiji" and the years between 1908 and 1921 were called "Taisho." Currently Japan is in the period of "Showa." These three names Meiji, Taisho, and Showa, which designate three generations represent three stages of age 
structure. At the same time it is a common understanding among the Japanese that these three names reflect conservativeness, moderateness, and progressiveness in their life style respectively. Each generation also seems to represent a different degree of Japanese traditional values.

During the reign of Emperor Meiji "the West" referred to Europe. But after W.W. II, "the West" meant America, and the U.S. was the country with which the Japanese strived to catch up. Political and economic contacts between the U.S. and Japan have been increasing with unprecedented speed, and cultural ties have been strengthened along with political and economic ties. The Japanese have been exposed to a great influx of American cultural phenomenon since the War and they have been absorbing the American culture with great enthusiasm, as they did the Chinese culture in their early history and European culture during the Meiji period. The Japanese culture and way of life was totally different from the American culture one hundred years ago, but the Japanese today seem to have been sharing a significant amount of American culture with the contemporary Americans. For example, the development of mass communication technology brought about an import of a significant number of American TV programs, movies, and music. Japanese mass media brought American culture directly into the Japanese home. The U.S. "occupied" Japan not only politically, but also culturally by invading the Japanese living rooms. "Lassie" became the best-known dog in Japan and the 
"Lone Ranger" kept the Japanese children in front of TV every week. The "Rifleman" replaced the traditional hero from its long-held position. Paul Anka, Neil Sedaka, and Elvis Presley dominated the Japanese radio while Hollywood movies flooded the Japanese theaters. The "Sengo" generation Japanese who have been brought up after the War can be said to have been exposed to the above-mentioned cultural milieu which is totally different from the one the "Senchu" and "Senzen" generations have experienced. Furthermore, the "Sengo" generation shared two of the most significant events in the post-war world. Student revolt shook Japan as it did Europe and the U.S. in the late '60s. Even though Japan did not send any young Japanese to Vietnam, the war in Vietnam was an element in the personal history of many "Sengo" Japanese.

The "Sengo" have not only been brought up under a shower of American popular culture, but also have received a very different education from the Japanese "traditional" education enjoyed by their parents. The post-war education placed an emphasis on democracy and individualism. The Japanese emperor who was formerly regarded as a founder and supreme power of the country now became only a symbol of the nation. The democratic decision-making process was encouraged not only among educators, but also among the students, to enhance the newly-established Japanese democracy. Individual achievement not found in the traditional Japanese 
values was also encouraged in both academic performance and extra-curricular activities.

According to Joseph Klapper (1) who studied the effects of mass communication on the people's voting in a political campaign, mass communication effect does not change people's attitude and values. However, it is the opinion of the author that today's Japanese youth seems to present a different profile from their generation-old countrymen and women, and some of their characteristics seem to be remarkably close to their American counterparts. This could be a result of the above-mentioned cultural and educational circumstances in which members of the "Sengo" generation have grown up.

The Japanese prime minister's office conducted an eleven-country youth attitude survey in 1972. The result of this survey provides us with interesting findings in regard to some similarity of opinion among the Japanese and American youth even though much of the survey reported differences in their opinion. For example, answering the question, "Why do you think man works?" $54.5 \%$ of the Japanese youth and 59.48 of the American youth chose "To earn money." $10.9 \%$ of the Japanese respondents and 11.28 of the American respondents answered, "To do his duty as a member of society," and 34.58 of the Japanese and 30.38 of the Americans answered that man works "to find self-fulfillment."

Beyond the Japanese and American similarity implied by the above data, there may even be the reversal of values 
regarding the Japanese and European youth. The report published in 1973 by Tamotsu Sengoku and Atsuko Toyama concluded that the new type of the Japanese was emerging when it stated,

While the Europeans showed gentleness to others the Japanese do not possess the same kind of gentleness. The Japanese lack affection. They clearly lack assertive kindness. They believe that man is fundamentally bad and the only person they can trust is themselves. Where has that Japanese 'mutual dependence' gone? Their belief that they trust only themselves is nothing but a European individualism. Japan and Europe are now completely reversed. (translated by the writer)

This conclusion does not necessarily indicate any extended similarity of values between Japan and the U.S., but presents a trend of attitude change undergoing among the Japanese youth.

Another research conducted in 1966 by Frank Berrien, Abe Arkoff, and Shinkuro Iwahara reported changing values of the Japanese youth. They administered the Edwards Personal Preference Schedule to college students and their parents in Japan, Hawaii, and New Jersey and tried to discover the degree of value differences between college sons and daughters and their parents in the three different locations.

The result showed that there is a remarkable similarity in the direction of the differences between the generations regardless of where they live. The authors wrote, "Fathers or mothers in all three cultures are more like each other than are the parents and children within any of the cultures." (4) 
There is another phenomenon which the Japanese youth experienced that their predecessors did not. Around 1960, Japan's economic miracle prompted many international observers to analyze the possible cause(s) of Japan's success story, which eventually turned into a series of analyses of the Japanese personality and values. Triggered by the international journalists' attempts to analyze Japan, the Japanese themselves started openly and seriously talking about what makes the Japanese Japanese. No other generation of Japanese has ever. lived in the midst of heated discussion on what makes themselves what they are and how they are different from other people. The heat has subsided now, but its impact on today's youth certainly cannot be dismissed. They are the first Japanese who can view themselves from the third party's perspective during their personality formation period.

It is the findings reported above, new experiences of the Japanese youth, and this writer's personal insight that initiated this research.

Purpose and Rationale of the Study

As stated previously, the American culture has been the most influential element in postwar Japan. Today's Japanese college students seem to feel much closer to the U.S. than their generation-old counterparts. They may share much more similar experiences with American students than they do with their parents. They find it comfortable to wear a 
T-shirt and a pair of jeans, not a kimono. They also find it very easy to identify with a baseball game, rather than a Sumo match.

On the other hand, there is no doubt that the Japanese college students have been exposed to traditional Japanese culture during their life. But the young "Sengo" Japanese believe their "Senchu" parents have been the embodiment of the traditional values and way of life. Their "Senzen" grandparents are living in "their own world."

There is also an argument that mass communication changes neither people's attitude nor values. It would follow that selective exposure and perception limit change of the "Sengo" Japanese. It may be that the "Sengo" Japanese still share the same old attitudes and values in spite of the massive influx of American culture by the theory that people do not pay attention to what they do not care for. The new educational philosophy introduced by the postwar government does also seem to have an effect on the attitude and values of the "Sengo" Japanese. On top of cultural similarity and the new education, waves of discussion on what makes the Japanese Japanese seem to be a factor involved in the personality development of the "Sengo" generation.

In light of the above discussion, it seems to be a worthwhile undertaking to investigate whether or not there is similarity of values between American and Japanese college students. 
In order to answer the above-mentioned question, the following research hypothesis will be used:

There is a positive relationship between the value system of the Japanese college students and that of American college student.

To test the above research hypothesis, the following null hypotheses will be tested in the present research:

1) There is no similarity between the value system of the Japanese male college students and that of American male college students whose ages are between 18 and 22 .

2) There is no similarity between the value system of the Japanese female college students and that of American female college students whose ages are between 18 and 22 .

3) There is no similarity between the value system of the Japanese college students (male and female) and that of American college students (male and female) whose ages are between 18 and 22 .

\section{Justification}

There have been many studies in the past which presented the "uniqueness" and "differences" of the Japanese culture, particularly personality and values, but few studies have been done to investigate possible similarity between Japan and other cultures, particularly, the American culture. Nor has there been any study which investigated the effects on the young Japanese people's attitude and values upon exposure to American culture.

Needless to say, the past studies helped to increase people's understanding about the Japanese and its culture. They also made the Japanese people realize how they are 
different from the rest of the world, particularly American culture. These studies have not increased awareness of the similarities which may exist and which, if accented, could bring the two cultures closer together.

It is the opinion of the author that as long as the people realize the differences, they may be able to avoid misunderstanding and misconception. But realization of the differences does not create closer relationships between two different cultures. People who share similar values tend to be attracted to each other. When people have different backgrounds and values, they may understand each other, but it is still difficult for them to come closer.

It is the above-mentioned perspective that led this writer to this investigation of a possible similarity in values. If the result of this survey proves the hypothesis presented in the previous section, it will not only fill the blank left behind by the studies which described only "uniqueness" of the Japanese culture, but also it will make a significant contribution toward strengthening the relationship between Japan and its people and other countries, the U.S. in particular. 


\section{FOOTNOTES--CHAPTER I}

${ }^{1}$ Joseph Klapper, The Effect of Mass Communication, (New York: Free Press, 1960), p. 8 .

2 Tamotsu Sengoku, and Atsuko Tohyama, Hikaku NihonjinIon (World Youth Survey) (Tokyo: Shogakkan, 1973), p. 140 .

${ }^{3}$ Ibid., p.: 259 .

4 Abe Arkoff, Frank Berrien, and Shinkuro Iwahara, "Generation Differences in Values: American, JapaneseAmerican, and Japanese," Journal of Social Psychology, 1967, $71,169-175$. 


\section{REVIEW OF THE LITERATURE}

General Definition of "Values"

According to Ethel Albert,

A value system represents what is expected or hoped for, required or forbidden. It is not a report of actual conduct, but is the system of criteria by which conduct is judged and sanctions applied. (1)

Clyde Kluckhohn (2), distinguishing values and beliefs, regards values as normative propositions, not existential, with which we judge goodness or badness of thoughts and behaviors. Charles Morris with his philosophical background conceives of values as "ways of life" and presents thirteen "ways to live." For example, his "Way l" reads as follows:

In this 'design for living' the individual actively participates in the social life of his community, not to change it primarily, but to understand, appreciate, and preserve the best that man has attained. Excessive desires should be avoided and moderation sought. One wants the good things of life but in an orderly way. Life is to have clarity, balance, refinement, control. Vulgarity, great enthusiasm, irrational behavior, impatience, indulgence are to be avoided. Friendship is to be esteemed but not easy intimacy with many people. Life is to have discipline, intelligibility, good manners, predictability. Social changes are to be made slowly and carefully, so that what has been achieved in human culture is not lost. The individual should be active physically socially, but not in a hectic or radical way. Restraint and intelligence should give order to an active life. 
Development of his thirteen "ways to live" is based on a combination of three basic concepts of the human personality, namely, "dionysian," "promethean," and "buddhistic." The "Way 1" described in the previous page is the way in which the "buddhistic" component is the strongest.

Franz Adler (4) sees values in four different ways. He presents the following four "meanings" of values 1) absolute qualities inherent in events or in contemplated states of affairs, 2) characteristics of objects as apprehended by people, 3) characteristics of the people who do the evaluating, and 4) the actual behaviors of people toward objects. William scott (5) who did a study of values among the sorority and fraternity students at the University of Denver in 1964, argues that values are those characteristics of people that we like to see in others. Scott, referring to Adler's four classifications of Values; defines as values ...an individual's concept of an ideal realtionship (or state of affairs), which he used to assess the 'goodness' or 'badness,' the 'rightness' or 'wrongness' of actual relationships that he observes or contemplates. (6)

This definition is close to that of Kluckhohn's, but according to Kluckhohn's criteria, Scott's definition does not differentiate values and beliefs. Scott's definition of values encompasses "values" and "beliefs" in Kluckhohn's term.

Triandis, presenting many works on values in his book, The Analysis of Subjective Culture (7), does not give us a clear definition of values, but he notes that the work of 
Kluckhohn and of Morris meet his criteria of an empirically useful definition.

According to another specialist on values, Milton Rokeach (8), beliefs, attitudes, and values form a hierarchical structure. His construct is an organization of several beliefs on a specific object and values are defined as a "preferable mode of conduct and end-state of existence." He calls "preferable mode of conduct" instrumental values and "preferable end-state of existence" terminal values.

For the purpose of this research, the writer takes, as an operational definition, Scott's definition which stated:

... an individual's concept of an ideal relationship (or state of affairs), which he used to assess the 'goodness' or 'badness,' the 'rightness' or 'wrongness' of actual relationships that he observes or contemplates. (9)

Review of Studies on Japanese Culture and Values

In this section various studies which describe "uniqueness" and "difference" in Japanese culture and values will be briefly reviewed. Included will be those studies conducted by i) psychologists and psychiatrists, ii) anthropologists and sociologists, and iii) intercultural communication researchers.

Psychologists and psychiatrists. One of the most prominent international observer of the Japanese youth is Robert Lifton. In 1961 he conducted an extensive interview 
with young Japanese and published a very interesting account of the psychological change they were undergoing, called Youth and History: Individual Change in Postwar Japan.

His discussion centered around detailed examination of such concepts as "Kokutai," and "Shutaisei" which were main concerns of the Japanese youth in the early '60s. "Kokutai" was interpreted by him as

...'national polity' or 'national essence,' but it also conveys the sense of 'body' or 'substance,' and its nature is impossible to define precisely. (10)

In regard to "Shutaisei," he wrote,

One feels this tension between the ideal of individualism and the need for the group in the concern of young people with that much-discussed, elusive, sometimes near-mystical, but always highly desirable entity known as Shutaisei. Shutaisei literally means 'subjecthood' and is a modern Japanese word derived from German philosophy coined by Japanese philosophers to introduce into Japanese thought the German philosophical ideal of man as subject rather than object. (11)

He also discussed a contact between group-oriented Japanese interpersonal relationship and postwar individualism and presented a convincing conclusion when he said, There is first the conscious ideal, the symbolic direction which a large portion of young people chart out for their own character structure. They wish to be and are to some extent becoming, 'new,' progressive, innovative, and anti-traditional, active, individually independent and socially committed. (12)

In 1961 William Caudill presented another aspect of the Japanese culture through his study of Japanese psychiatric hospitals, entitled "Around the Clock Care in Japanese Psychiatric Hospital." He focused his attention on an 
analysis of a role of "Tsukisoi," a female caretaker assigned to an individual patient who sleeps in the same room as the patient and serves as housekeeper and companion. His "observation and interview" research concluded:

....interdependence and the expression of tenderness are well served in the Japanese psychiatric hospital though probably at the cost of the sufficient encouragement of individuality and the expression of aggression. And the same thing might be said more generally of Japanese culture, within which the adaptive use of interdependence and tenderness are highly developed, but where the rub comes is in the difficulty experienced in finding one's individuality and in the controlled use of aggression. (13)

Among Japanese psychiatrists, Takeo Doi's work is worth mentioning. In his book, Amae no Kohzoh (The Structure of Dependence) published in 1971, he analyzed the Japanese personality, the core of which is occupied by "Amae (dependence)" syndrome. Doi writes,

This dependence, the amae of a child toward its parent, of a student toward his teacher, of a company employee toward his superiors, of a junior toward his senior (in school or university terms) is considered utterly natural in Japanese society. Amae, a Japanese would say, is surely something essentially innocent, something indispensible in cementing human relationships. (14)

Anthropologists and Sociologists. While Robert

Lifton, William Caudill, and Takeo Doi did their respective work based on first-hand observation and interview, Ruth Benedict did her insurmountable research without having ever visited Japan. Yet, her book, The Chrysanthemum and the Sword seems to depict the essence of the traditional Japanese characters. 
She found the core of the Japanese character in their never-ending performance of duty and obligation. According to Benedict, the Japanese character

...was in large measure the product of explicit training in the need for self-sacrificing pursuit of duty--of duty towards the Emperor, the nation, the family, status, superior and personal benefactors, and of the duty to maintain one's group --a preoccupation which made shame rather than guilt the major moral sanction. (15)

This view on duty and obligation is shared by a noted Japanese scholar, Chitose Yanaga. He wrote,

Perhaps no other emotional force in Japanese society is as powerful and propulsive as that which inheres in the sense of obligation or indebtedness which is known as ON. From the cradle to the grave, this emotional force, in all its variations and manifestations, propels the individual in his actions. Life is an endless succession of favors received for which repayment must be made with diligence. The social behavior of the people becomes unintelligible without adequate consideration of this peculiarly Japanese concept and practice. The fabric of society is thus woven with the warp and woof of mutual and reciprocal indebtedness and obligations. Obligations bind the individual to individuals and groups in a tight web of relationships which ignores individual rights and desires. What exists is a hierarchy of obligations beginning at the top with loyalty to the Emperor and the state, to society at large, to the family as manifested in filial piety, to one's superiors, teachers, friends, inlaws, and even to subordinates and servants. (16)

Regarding "ON," Benedict presented a list of "ON" under the heading, "Schematic Table of Japanese Obligations and.Their Reciprocals." A part of the list read as follows:

1. ON: obligations passively incurred. One 'receives an ON'; one 'wears an ON,' i.e., ON are obligations from the point of view of the passive recipient. 
Ko ON: ON received from the Emperor Oya ON: ON received from parents Nushi No ON: ON received from one's lord Shi No ON: ON received from one's teacher (17)

Whether or not these concepts, not to mention words, are still in the core of the Japanese minds is another question. However, there is no doubt that Benedict presented the detailed analysis of the Japanese culture and its traditional values as of W.W. II, the time Benedict's work was done.

There is an anthropological work which was conducted in the mid-'60s which presents a more recent description of Japanese personality and values. A Canadian-born anthropologist went to Japan in 1964 and observed one urban and one rural community during his stay. In his book, Changing Japan, Edward Norbeck spared one section for his account of Japan's modernization and commented on changing Japanese values. He asserted that Japanese traditional values such as achievement, industry, self-control, and group orientation continued to exist, but he presented two examples of changing values.

He found the growth of individualism as one example of change. He also recognized another change in Japanese people's attitude toward happiness when he wrote,

...the pursuit of happiness, a concept that implies maintenance of moral standards and thus does not precisely coincide with pleasure, has become a worthwhile goal of life. Once viewed as an immoral doctrine that threatened the achievement of proper goals of fulfilling obligations, the quest of happiness is an ideal that has gained wide acceptance throughout the nation. (18) 
R. P. Dore, a British sociologist, whose work is represented by the book called City Life in Japan published in 1959, described life in one of wards in Tokyo in his book. He later gave an account of the Japanese personality in contrast to the Englishman in 1969. According to his observation, the Japanese are 1) less self-confident and more preoocupied with retaining the good opinion of others, 2) mare imitative, 3) more ambitious, 4) more slavishly diligent, 5) more submissive to superiors, 6) less willing to stand up for individual rights, 7) more dishonest and indirect in speech, 8) less 'men of principles', 9) less sense of social responsibility to remove abuses in their own society, 10) more childishly naive, 11) more introvert, 12) more sentimental.

The above are characteristics of the Japanese as identified by Dore, and the writer believes some of them do reflect values the Japanese find important. For example, the fourth characteristic, "more slavishly diligent," certainly describes the importance the Japanese attach to diligence. The seventh feature could be interpreted as a value of respect for others.

Intercultural communication researchers--crossqultural value studies. The studies mentioned in the previous two sections are well recognized, but only a sample of similar works. They mainly describe the Japanese personality and behavior and do not discuss nor investigate 
specific values of the Japanese. There are, however, several researchers who studied Japanese and also American values.

The first study on Japanese values was conducted by William Caudill and Harry Scarr in 1955. They applied a value orientation approach developed by F. Kluckhohn to 619 Japanese subjects in Tokyo, Chiba, and Ome, Japan.

The value orientation schedule administered by Caudill and Scarr was essentially the same as the original one by Kluckhohn. It asked the respondents to rank order three solutions for each question, with topics ranging from "How to help in case of misfortune" to "The relationship between man and God."

The following is an example of a value orientation question:

A man had a crop failure or, let us say, had lost most of his cattle. He and his family had to have help from someone if they were going to get through the winter. There are different ways of getting help, as in the following,

1) Would it be best if he depended on his brothers and sisters or other relatives all to help him out as much as each one could?

2) Would it be best for him to try to raise the money on his own, without depending upon anybody?

3) Would it be best for him to go to a boss or to his head house (honke), and ask for help until things got better? (20)

Twenty-three questions such as above were included in the schedule. Caudill and Scarr then compared the result of rankings to each question by Japanese and American subjects. 
The 619 Japanese respondents consisted of 277 high school senior students and 342 of their mothers and fathers and the rankings by the young Japanese and the older Japanese were also compared to see possible value change.

After a careful analysis of each question, the authors concluded,

First, in terms of sheer amount, children have moved away from the value orientations of their parents relatively little. Second, this little movement is distributed unequally over the four behavior spheres. Most of it occurs in political life, moderate amounts in family and occupational life, and only a slight amount in religious life...(21)

It should be added, however, that the subjects of this study, the high school seniors in 1955, are the "Senchu" Japanese, not the "Sengo" Japanese the present research purports to investigate.

In 1964, Frank Berrien (22), tested 855 Japanese high school students and 962 college students in Japan by the Edwards Personal Preference Schedule (EPPS) and compared the result with 1,509 American college students' response.

The EPPS was constructed by H. A. Murry and his colleagues in 1938 to measure the' personal preferences of the epople on fifteen needs, namely, Achievement, Deference, Order, Exhibition, Autonomy, Nurturance, Change, Endurance, Heterosexuality, and Aggression.

Berrien hypothesized that 1) the Japanese would score higher in deference and abasement and lower in dominance than the American sample, and 2) the Japanese college students would be moving toward American values while Japanese 
high school students would be "laggards" in their value change.

The result supported only partially the first hypothesis because it indicated that

1) Japanese college men were lower in achievement, deference, and dominance, but higher on abasement, endurance, and change, and 2) college women were lower on achievement, deference, affiliation, dominance, and nurturance, but higher on aggression than their counterparts in America. (23)

In regard to the second hypothesis, Berrien concluded, ...the result then of the acculturation hypothesis indicate that Japanese males appear to be approaching American values in the categories of order, change, possibly introception, but Japanese women are immune to these influences and may even be moving in the opposite direction in at least some areas, namely, achievement and nurturance. (24)

In 1966 Berrien, together with Abe Arkoff and Shinkuro Iwahara, conducted another research to discover to what degree the parents of college students in Japan, the U.S., and the Japanese-Americans in Hawaii have value patterns coordinate with those of their parents. He again used the EPPS and sampled 100 college daughters and their mothers and 100 college sons and their fathers in Tokyo, 100 daughter-mother pairs and 99 son-father pairs of the Japanese-American in Hawaii and 100 daughter-mother pairs and 56 son-father pairs in New Jersey. He hypothesized that the value patterns would be more different between the Japanese parents and their college students than in either of other settings. The result showed that there is a remarkable similari.ty in the direction of the differences between the 
generations regardless of where they live. Berrien wrote,

Fathers or mothers in all three cultures are more like each other than are the parents and children within any of the cultures. Furthermore, the Japanese and Japanese-American sons are more like each other than they are like their fathers, and the same is true for the Japanese-Americans and the American sons. On the female side similar comparisons show that Japanese-American and American daughters are more highly correlated than either group is with their respective mathers. Only the Japanese daughters are more like their mothers than they are like daughters in the other two samples. (25)

While two studies by Berrien and his colleagues involved the EPPS as a testing instrument, Akio Kikuchi and Leonard Gordon conducted their research on Japanese and American personal values in 1968 by using their own instrument called KG-Survey of Personal Values (KG-SPV). The KG-SPV measures six values such as Practical mindedness, Achievement, Variety, Decisiveness, Orderliness, and Goal orientation.' It consists of 30 forced-choice blocks of three statements each. The respondents were asked to choose one statement "most important" to him and one statement which is "least important" from three statements. For example one set of statements asked the respondent to choose "the most important" and "the least important" from the following three statements:

1) To do things I never did before

2) To do more than is generally expected of me

3) To know exactly what I am aiming for (26)

The number of the respondents was varied depending on the answers obtained, but it included 700-1,000 Japanese 
students and more than 1,000 American students from similar educational and socio-economical backgrounds.

The authors concluded that there is a very high degree of similarity between the Japanese and American personality structure, but they did not present any statistical data to support it. There seem to be significant differences in some values. For example, the Japanese students showed significantly lower mean value than the American counterparts in Practical mindedness, Achievement, and Variety and higher mean yalue in Orderliness and Goal Orientation.

However, it should be mentioned that the KG-SPV as a value measuring instrument measures a very limited area of people's values compared to Kluckhohn's Value Orientation approach and the EPPS. Gene Glass commented on the KG-SPV's limitation in the seventh Mental Measurement Yearbook when he wrote,

These six scales (of KG-SPV) are based on the small coin of human motivation; they hardly possess the romantic appeal and fundamental significance of Spranger's six types of men in the study of Values.

The present research will adopt a value list approach to solve the KG-SPV's limitation. The value list will be designed to cover a considerably wider area of personal values than the KG-SPV. 
FOOTNOTES--CHAPTER II

${ }^{1}$ John C. Condon and Fathi Yousef, An Introduction to Intercultural Communication (Indianapolis: Bobbs-Merril Co., 1976), p. 50 .

${ }^{2}$ clyde Kluckhohn, "Values and Value orientations in the Theory of Action: An Exploration in Definition and Clarification," in Toward a General Theory of Action, edited by Talcott Parsons and Edward Shils (Cambridge: Harvard University Press, 1951), p. 390-406.

${ }^{3}$ Charles Morris, Varieties of Human Values (Chicago: University of Chicago Press, 1956), p. 15.

${ }^{4}$ Franz Adler, "The Value Concept in Sociology," American Sociological Review, 1956, 62, p. 272-279.

5 William Scott, Values and Organization (Chicago: Rand MCNally, 1965), p. 3 .

${ }^{6}$ Ibid., p. 3 .

${ }^{7}$ Harry Triandis, The Analysis of Subjective Culture (New York: John Wiley, 1972), p. 16.

${ }^{8}$ Milton Rokeach, The Nature of Human Values (New York: Free Press, 1973), p. 5.

${ }^{9}$ William scott, op. cit., p. 3.

${ }^{10}$ Robert Lifton, "Youth and History: Individual Change in Postwar Japan," in The Challenge of Youth edited by Erik H. Erikson (New York: Doubleday, 1965), p. 270 .

${ }^{11}$ Ibid., p. 273.

${ }^{12}$ Ibid., p. 283. 
13 William Caudill, "Around the Clock Care in Japanese Psychiatric Hospital," American Sociological Review, 26 : 204-214, 1961.

14 Takeo Doi, The Structure of Dependence (Tokyo: Kodansha International, 1971), p. 20 .

${ }^{15}$ R. P. Dore, "The Japanese Personality," in Asia Handbook edited by Guy Wint, (Harmondsworth: Penguin Books, 1969), p. 492 .

${ }^{16}$ Chitose Yanaga, Japanese People and Politics (New York: John Wiley and Sons, 1956), p. 58-59.

17 Ruth Benedict, The Chrysanthemum and the Sword (London: Routledge and Kegan Paul, Ltd., 1967), p. 116.

${ }^{18}$ Edward Norbeck, Changing Japan (New York: Holt, Rinehart and Winston, 1965), p. 21 .

${ }^{19}$ R. P. Dore, op. cit., p. 495.

${ }^{20}$ William Caudill and Harry Scarr, "Japanese Value orientation and Cultural Change," Ethnology, Vol. 1, No. 1, 1962, p. 61.

\section{${ }^{21}$ Ibid., p. 89.}

22 Frank Berrien, "Japanese and American Values," International Journal of Psychology, Vol. 1, No. 2, 1966.

$$
\begin{aligned}
& 23 \text { Ibid., p. } 125 . \\
& 24 \text { Ibid., p. } 138 .
\end{aligned}
$$

25 Abe Arkoff, Frank Berrien, and Shinkuro Iwahara, "Generation Differences in Values: American, JapaneseAmerican, and Japanese," Journal of Social Psychology, 1967, 71, 169-175.

\section{${ }^{26}$ Leonard Gordon, The Survey of Personal Values:} Manual (Chicago: Science Research Associates, 1956), p. 4. 
27 Gene Glass, "Review on the SPV," in The Seventh Mental Measurement Yearbook edited by O. K. Buros, (New Jersey: Gryphon Press, 1972), p. 148 . 
CHAPTER III

\section{METHOD AND SAMPLE}

Method

There are five major value-measuring instruments or schedules developed by various researchers in the past for a single-culture survey or a cross-cultural research. Most of these instruments were designed originally for a singleculture value research and then translated, with modification, into other languages for carrying out cross-cultural research.

The instrument most widely known and used is the study of Values. It was originally published in 1931 by Allport and Vernon, and since then two new editions were added in 1951 and 1960. It aims to measure the relative prominence of six basic interests or values in personality: theoretical, economic, aesthetic, social, political, and religious. The six basic values were derived from E. Spranger's Types of Men (1928). According to Spranger, a German philosopher, the six types of men are described as follows:

1) The theoretical: The dominant interest of the theoretical man is the discovery of truth. Since the interests of the theoretical man are empirical, critical, and rational, he is necessarily an intellectualist, frequently a scientist or philosopher.

2) The economic: The economic man is characteristically interested in what is useful. This 
type is thoroughly "practical" and conforms well to the prevailing stereotype of the average American businessman.

3) The aesthetic: The aesthetic man sees his highest value in form and harmony. Each single experience is judged from the standpoint of grace, symmetry, or fitness.

4) The social: The highest value for this type is love of people. The social man prizes other persons as ends, and is therefore himself kind, sympathetic, and unselfish.

5) The political: The political man is interested in power. His activities are not necessarily within the narrow field of politics; but whatever his vocations, he betrays himself as a Machtmensch.

6) The religious: The highest value of the religious man may be called unity. He is mystical, and seeks to comprehend the cosmos as a whole, to relate himself to its embracing totality. (1)

The test consists of a number of questions for which two or four alternatives are provided. The subjects are asked to indicate his preference numerically.

The most widely criticized point of the study of values lies in its theoretical base, i.e., Spranger's six types of men. Robert Hogan, in the Seventh Mental Measurement Yearbook (1972), criticized the adequacy of the spranger's types as a taxonomy of personality while admitting that there is nothing in the nature of spranger's types per se that makes them unacceptable as a theoretical base for a test. He wrote,

First, as a result of the manner in which the scales are defined conceptually, individual characterization derived from the Study of Values are always honorific. There are no provisions within the system to classify blackguards, villains, or demonic man. Second, the types have a pervasive middle-class flavor. (2) 
The Edwards Personal Preference Schedule (EPPS) was

based on a set of needs developed by Henry Murry and his colleagues at the Harvard Psychological Clinic in 1938. Berrien and his colleagues used the EPPS in two researches reviewed in the previous chapter.

There are two major criticisms against the EPPS. The first one is in regard to the influence of social desirability, and the second criticism is related to the fakability of the EPPS. In regard to social desirability which the EPPS tried to control through the forced-choice technique, Ann Anastasi wrote in her Psychological Testing (1976), "It appears that the forced-choice technique has not proved as efficient as had been anticipated in controlling faking or social desirability."

As for fakability of the EPPS, Bernard Borislow is his article, "The EPPS and Fakability," reached a conclusion that it can be faked under structured personal and social desirability instructions.

The KG-SPV used for Gordon and Kikuchis' study of Japanese and American values is a modified version of the study of Personal Values (SPV) originally developed by Gordon in English. The KG-SPV has proven a high reliability and crosscultural reliability. Gordon and kikuchi examined thirty representative items in the Japanese KG-SPV and factor-analyzed them. The result showed that the six original dimensions emerged as factors. They conducted test-retest reliability studies on the Japanese version and obtained 
correlation coefficients ranged from .60 to .77. They also investigated the construct validity of the Japanese KG-SPV in terms of the correlations of its scales with those Japanese personality tests such as Yatabe-Guilford, Kikuchi-Gordon Survey of Interpersonal Values, and DOSEF. The riesult indicated significant validity. However, it should be noted that the KG-SPV was criticized on the ground that it measures a limited area of values or personality.

On the other hand, Harry Triandis seems to evaluate the KG-SPV highly. He mentioned two important elements for cross-cultural testing instruments in his book, The Analysis of Subjective Culture (1972). They are scale construction and independent validation in each culture. He also wrote,

In general, the forced-choice technique appears to be most promising in achieving both reliability and coverage in a limited amount of time. (4)

The KG-SPV did not go through the process of scale construction in the Japanese language, but it meets the two recommendations Triandis advocated. It was validated independently in Japan and the U.S. and also utilized the forcedchoice technique. But it should be noted that Anastasi and others have a strong doubt about effectiveness of the forcedchoice technique.

Another important value-measuring instrument was developed by Milton Rokeach. Rokeach, organizing beliefs, attitudes, and values in a hierarchical structure, presented that concept of value system. He wrote, 
An adult probably acquires tens of thousands of beliefs, thousands of attitudes, but only dozens of values. A value system is a hierarchical organization--a rank ordering--of ideals or values in terms of importance. (5)

Based on this definition, he developed value lists to be ranked by the respondent. He constructed two separate value lists for his "terminal values" and "instrumental values." His terminal value list consists of the following end-states:

1) a comfortable life

2) an exciting life

3) a sense of accomplishment

4) a world at peace

5) a world of beauty

6) equality

7) family security

8) freedom

9) happiness

10) inner harmony

11) mature love

12) national security

13) pleasure

14) salvation

15) self-respect

16) social recognition

17) true friendship

18) wisdom

The eighteen instrumental values are:

1) ambitious

2) broad-minded

3) capable

4) cheerful

5) clean

6) courageous

7) forgiving

8) helpful

9) honest

10) imaginative

1I) independent

12) intellectual

i3) logical

14) loving

15) obedient

16) polite

17) responsible

18) self-controlled 
The value list approach represented by the Rokeach's list is criticized by Condon (1975) on three points. Condon (1975) pointed out the ambiguity of the list, the language of values, and a risk of generalization as the value-list approach's weak points. In regard to ambiguity, he wrote,

We may read, for example, that Americans value equality, fair play, progress, and self-reliance, often without reading any explanation of how such values function or how they are related. Like other explanations that are 'clear only if known,' such a list may be convenient and seem accurate to someone familiar with the culture described, but it may be misleading to someone who has no other information to rely upon. (6)

However, Leona Tyler, referring to Rokeach's actual research in 1968 with the sample of 1,409 American adults, evaluated his list highly as an instrument for group comparison. She mentioned a high reliability of rankings and the simplicity of the technique as advantages, although she noted that the value list has too low internal correlation to make any sort of individual prediction possible.

All four instruments mentioned above were originally constructed in English and three of them have been translated into Japanese for cross-cultural research purposes. But the next and last one, a value orientation approach, was designed for specifically cross-cultural use by F. Kluckhohn and F. Strodtbeck and actually used for Japanese and American value research by $W$. Caudill. The value orientation questionnaire asks the respondent to rank order three alternatives for each problem-solving situation. 
Condon mentioned two limitations of the value orientation approach. The first limitation is of universality of situations to solve. He wrote,

The particular situations proposed are crucial in the interpretation of the orientations and if the method is to be used for comparative studies it may be difficult in some cases to find comparable situations for very different cultures.

The second limitation is concerned with the deductive nature of the value orientation approach. He noted the problems involved in selecting appropriate situations and solutions to present to the respondents.

All in all, the above-mentioned five approaches or instruments have advantages and disadvantages. In the present research the value list approach was adopted. There are four reasons for using it: 1) the value list can encompass a considerably wide area of the value system, which the SV completely fails to do, 2) it can depict the internal structure of the value system, which the SV, the EPPS, and the KG-SPV cannot achieve, 3) when it is administered, its implicity, without imposing too many questions on the respondents, makes it possible to depict a certain group's value system in the shortest amount of time, and 4) construction of the original value list for two cultures, namely American and Japanese, is practical with limited research time.

In response to Condon's criticism of the value list approach, maximum effort was made to assure clarity of values in translation. As for a risk of generalization, it should be remembered that any research cannot be free from the risk 
of generalization unless its sampling covers all possible members of the target group.

It should be also noted that the present value list satisfied one of Triandis' recommendations for cross-cultural research since the list construction was made in both the Japanese and English languages. However, it should be added that independent validation in the U.S. and Japan has not been conducted.

The value list for the present research was constructed by the writer himself, initially. First, ten American values and twelve Japanese values were collected by the writer from various literatures on Japan and the U.S. which included Frank Gibney's Japan: The Fragile Superpower, Herman Kahn's The Emerging Japanese Superstate, F. Kluckhohn and E. Strodtbeck's Variations in Value Orientations, and E. C. Stewart's American Cultural Patterns besides those mentioned in the previous chapter. Then the writer translated the Japanese values into English and American values into Japanese. The writer next checked his own translation of the Japanese values through discussion with some of his bilingual colleagues at Portland State University. Then the twelve translated Japanese values were presented to three bi-lingual Japanese for back-translation. Also the ten American values were translated into Japanese by the same people. to maximize the quality of translation of the American values. 
The number of values was reduced to fifteen, first by eliminating the redundant values and integrating similar values, and second, by consulting an anthropologist and communication scientists who are familiar with both cultures. Values which have shown or may show contrast between American and Japanese culture were chosen to minimize internal bias of the list toward similarity. In addition, the salience of the values in both cultures was taken into consideration. In at least one case ("Diligence"), the salience criterion outweighed the contrast criterion for inclusion. From statistical viewpoints, the fifteen values were judged as an adequate number for rank order correlation analysis by consulting with Dr. Ted Grove at PSU Speech Communication Department.

The final list consists of the following 15 values:

1) Deep understanding of the world

2) Diligence--hard working

3) Family unity

4) Fulfillment of obligation and duty among your friends and relatives

5) Group loyalty

6) Group success

7) Human equality

8) Independence

9) Individual achievement

10) Inner harmony

11) Personal happiness

12) Respect for others--avoiding friction with other people

13) Self-respect

14) Social status

15) A world of beauty

Eight of the fifteen values, "Deep understanding of the world," "Family unity," "Fulfillment of obligation and duty," "Group loyalty," "Group success," "Inner harmony," "Respect 
for others," and "Social status" are strongly Japanese according to the review of the literature. Five of them such as "Human equality," "Independence," "Individual achievement," "Personal happiness," and "Self-respect" are strongly American. However, one of them, "Diligence," is shared by both cultures and the fifteenth value, "A world of beauty," is a transcultural, or neutral value.

The description of the fifteen values and reasons for their selection are as follows:

1) Deep understanding of the world: Deep understanding of the world is a contrasting value to American materialism. Japanese culture has long encouraged and nourished people's high sensitivity and deeper appreciation of nature which is inextricable from human beings. Herman Kahn (8) pointed out the Japanese emphasis on the spiritual over the material as one of the characteristics of the Japanese mind. Frank Gibney (9) presented his account of the relationship between nature and the Japanese, referring to Zen Buddhism.

2) Diligence: Diligence characterizes both American and Japanese culture. In spite of effort to maximize contrast among the fifteen values, the writer was compelled to keep this value in the final list since it is certainly one of the strongest characteristics in the two societies. R. P. Dore (10) described one of the Japanese personality traits, as "more slavishly diligent." Gordon and Kikuchi's study (11) reported a higher score of the Japanese subjects on Goal orientation which is to some extent related to diligence. In American society, diligence seems to form a core of the American Puritan tradition.

3) Family unity: Family unity still seems to be a highly preferential value among the Japanese. It has been a center of the Japanese people's concern and values for a long time as Chitose Yanaga (12) mentioned in his Japanese People and Politics. E. Norbeck (13) also pointed out the importance of family unity and Caudill and Scarr's value orientation research (14) revealed a greater preference for Collateral relations in the area of "Family life." 
On the other hand, family unity in American culture, although it could be a major concern of many American families, seems to come behind encouragement of individual growth and independence.

4) Fulfillment of obligation and duty among friends and relatives: This value is originally called "Gili-ninjoh" in Japanese and has been ignored in all of the past studies, the testing instruments of which were originally in English. This is the unique value of the Japanese culture Ruth Benedict (15) described as THE Japanese value. It seems to be a remote concept for the Americans to understand that a son has an obligation to take care of his parents and that if a friend does a favor for you, you must return your indebtedness to him by all means.

5) Group loyalty and 6) Group success: These values have been described by many researchers as one of the traits which make the Japanese Japanese. R. P. Dore (16) stated, "The Japanese are more willing to forego the pleasures of self-assertion in the interests of social harmony," which seems to suggest it is related to this writer's twelfth value, "Respect for others--avoiding frictions with other people." H. Kahn (17) mentioned group loyalty referring to Samurai warriors' faithfulness to their lords. Robert lifton (18) pointed out group-oriented nature of the Japanese. M. E. Goodman's study (19) on the Japanese children found that they have substantially greater groupanchored achievement than individual achievement. It is possible to find this value of group loyalty or success in a sense among the sorority or fraternity students in the U.S., but no American employee seems to have a life-long commitment to his company as the Japanese company employee has. In the U.S., it may be inferred an individual's happiness or achievement comes first before a loyalty to the group or the group's success.

7) Human equality: E. C. Stewart wrote in his account on American culture,

Running throughout the American's social relationships with others is the theme of equality... When a personal confrontation is required between two persons of different hierarchical levels, there is an implicit tendency to establish an atmosphere of equality. (20) 
Equality is undoubtedly one of the American values throughout the history of the U.S. On the other hand, in a hierarchical Japanese society, equality seems to be a difficult relationship to establish even among family members. $H$. Kahn even went on to say,

The Japanese have very little concept of equality... The various Japanese words we would use as synonyms for 'equal' simply do not have an apposite meaning in that phrase. (21)

8) Independence and 9) Individual achievement: These values are derivatives of American individualism, which are strongly contrast to Japanese "Group loyalty" and "Group success." E. C. Stewart described these values as follows:
The American stress on the individual as a concrete point of reference begins at a very early age when the American child is encouraged to be autonomous... It is implicitly accepted that each child or person should be encouraged to decide for himself, develop his own opinions, solve his own problems, have his own things and, in general, learn to view the world from the point of view of the self. (22)

Gordon and Kikuchi's study reported the result that the American students valued "Achievement" higher than the Japanese counterparts. (23)

10) Inner harmony: This is also a Japanese antonym to American materialism. Buddhism and Zen Buddhism which developed such art forms as tea ceremony and flower arrangements pursue an individual's inner peace as an ultimate end.

11) Personal happiness: This is congruent with 9) Individual achievement in sense that both are derivatives of American individualism. The pursuit of personal happiness has been an openly and positively encouraged and fostered value in American society while, as Norbeck mentioned, the quest of happiness was viewed as a negative attitude among the Japanese. (24)

12) Respect for others--avoiding frictions with other people: This is described as a major characteristic of the Japanese behavior which seeks 
interpersonal harmony, avoiding confrontations. R. P. Dore pointed out this Japanese value by writing, "The Japanese are more sensitive to, and less willing to offend, the feeling of others."(25) This value could be, to some extent, an integral part of the American people, but not as strong as among the Japanese. It appears that, at least in many cases, the Americans are willing to risk interpersonal friction in the name of "honesty" and "straightforwardness."

13) Self-respect: E. C. Stewart wrote,

The concept of the self is an integral assumption of American culture, so deeply ingrained that Americans ordinarily do not question it. They naturally assume each person has his own separate identity which should be recognized and stressed. (26)

It is the writer's opinion that this value or word, when translated into Japanese, seldom becomes a topic of discussion among the Japanese. It seems to be the most remote Western concept to the Japanese in general who, as been mentioned, always identify themselves with a certain group.

14) Social status: In the hierarchical society like Japan, status has an important function and value in any interpersonal situation. Implication attached by the Japanese word, "social status," is immense. You must use a proper verbal expression to a higher-status person, and show him a respect. In any decision-making process, a higher-ranked person has a final word. In the U.S., social status definitely has a certain function, but it seems to be always challenged by the concept of equality as stewart mentioned.

15) A world of beauty: This is taken from Milton Rokeach's terminal value list and a neutral value which the writer assumed could be a factor in both Japan and the U.S. Furthermore, the writer assumed that this value, although no literature on Japan and the U.S. has ever mentioned, could be a new value emerging among the young in the world. It is possible for the Japanese to rank this value high and for the Americans to rank it low. The opposite response is also possible. The writer included this value which could either strengthen or weaken the contrast because of its significance as a possible new value. 
The actual questionnaire with the value list in both Japanese and English are attached in Appendix A and B.

The statistical analysis included rank order correlation and factor analysis.

The rank order correlation coefficient (Rho) was computed by the following formula:

$$
\text { Rho }=1-\frac{\sigma \sum_{i=1}^{i=N} d i^{2}}{N^{3}-N}
$$

where $\mathrm{N}$ is the number of values (15 values) and $\mathrm{di}$ is a rank difference of each value.

Sample

The subjects for the present research were drawn from three universities in Tokyo, Japan, and Portland State University in Portland, Oregon. The Japanese subjects consisted of 59 male and 24 female students from Dokkyo University, 70 male and 12 female students from Nippon University, and 22 male and 32 female students from the International Christian University. The total number was 219 .

The test was administered by Professor Hakaru Itami at Dokkyo University, Professor Takehide Kawashima at Nippon University, and Ms. Masako Sano and Mr. Susumu Tamba at the International Christian University. Professor Itami's subjects were drawn from his Economics classes. The subjects at Nippon University were obtained from Business and 
Accounting classes and the ICU subjects were taken from the Freshman English Program classes by Ms. Masako Sano and Mr. Susumu Tamba.

Age distribution of the Japanese subjects is presented in Table 1 below. The mean age of the Japanese subjects is 19.2 .

The American subjects were obtained from PSU's Speech Communication, Psychology, and German language classes and consisted of 60 female students and 55 male students with ages ranging from 18 to 22. The actual test was administered in the classes of Professor LaRay Barna, Professor Chad Karr, Professor Roger Jennings, Ms. Debbie Sullivan, Ms. Liz Powell, and Mr. Jeff Sweeney. Age distribution of the American subjects is shown in Table 2 on the next page. The mean age of the American subjects is 19.8 .

TABLE I

AGE DISTRIBUTION--JAPANESE

\begin{tabular}{lcccccc}
\hline $\begin{array}{c}\text { Age } \\
\text { Sex }\end{array}$ & 18 & 19 & 20 & 21 & 22 & Total \\
\hline Male & 41 & 54 & 35 & 18 & 3 & 151 \\
\hline Female & 26 & 27 & 9 & 4 & 2 & 68 \\
\hline Total & 67 & 81 & 44 & 22 & 5 & 219 \\
\hline
\end{tabular}


TABLE II

AGE DISTRIBUTION--AMERICAN

\begin{tabular}{ccccccc}
$\begin{array}{c}\text { Age } \\
\text { Sex }\end{array}$ & 18 & 19 & 20 & 21 & 22 & Total \\
\hline Male & 6 & 16 & 11 & 12 & 10 & 55 \\
\hline Female & 14 & 23 & 9 & 7 & 7 & 60 \\
\hline Total & 20 & 39 & 20 & 19 & 17 & 115 \\
\hline
\end{tabular}


FOOTNOTES--CHAPTER III

${ }^{1}$ Gordon Allport, G. Lindzey, and Philip Vernon, The Study of Values: Manual (Boston: Houghton Mifflin, 1 $\overline{970}$ ), p. 4 .

2 Robert Hogan, "Review on the SV," in The Seventh Mental Measurement Yearbook edited by 0 . K. Buros, (New Jersey: Gryphon Press, 1972), p. 146.

${ }^{3}$ Ann Anastasi, Psychological Testing (4th ed.), (New York: MacMillan, 1976), p. 459.

4 Harry Triandis, The Analysis of Subjective Culture (New York: John Wiley Sons, 1972), p.81.

5 Milton Rokeach, Value, Beliefs, and Organization (San Francisco: Jossey-Bass, 1968), p. 124.

${ }^{6}$ John Condon and Fathi Yousef, An Introduction to Intercultural Communication, (Indianapolis: Bobbs-Merril Co., 1976), p. 55 .

\section{${ }^{7}$ Ibid., p. 57.}

${ }^{8}$ Herman Kahn, The Emerging Japanese Superstate (Harmondsworth: 'Penguin Books, 1973), p. 66.

${ }^{9}$ Frank Gibney, Japan: The Fragile Superpower (Tokyo: C. E. Tuttle, 1975), p. 104 .

${ }^{10}$ R. P. Dore, "The Japanese Personality," in Asia Handbook edited by Guy Wint, (Harmondsworth: Penguin Books, 1969), p. 495 .

${ }^{11}$ Leonard Gordon and Akio Kikuchi, "Japanese and American Personal Values," International Journal of Psychology, 1970, Vol. 5, No. 3, 18 3-187.

12 Chitose Yanaga, Japanese people and Politics (New York: John Wiley, 1956), p. 59-60. 
13 Edward Norbeck, Changing Japan (New York: Holt, Rinehart and Winston, 1965), p. 31, 50.

14 William Caudill and Harry Scarr, "Japanese Value Orientation and Culture Change," Ethnology, Vol. 1, No. 1, p. 75 .

${ }^{15}$ Ruth. Benedict, The Chrysanthemum and the Sword (London: Routledge and Kegan Ltd., 1967), p. 99-110, 137176.

${ }^{16}$ R. P. Dore, op. cit., p. 495.

17 Herman Kahn, op. cit., p. 28-30.

18 Robert Lifton, "Youth and History: Individual Change in Postwar Japan," in The Challenge of Youth edited by Erik H. Erikson, (New York: Doubleday, 1965), p. 273.

${ }^{19}$ M. E. Goodman, "Value, attitude, and social concepts of Japanese and American children," American Anthropologists, 1957,59 , p. 979-999.

${ }^{20}$ E. C. Stewart, American Cultural Patterns (Pittsburgh: Regional Counci for International Education, 1971), p. 46 .

${ }^{21}$ Herman Kahn, op. cit., p. 24.

${ }^{22}$ E. C. Stewart, op. cit., p. 68-69.

${ }^{23}$ Leonard Gordon and Akio Kikuchi, op. cit., p. 185.

${ }^{24}$ Edward Norbeck, op. cit., p. 21.

${ }^{25}$ R. P. Dore, op. cit., p. 495.

${ }^{26}$ E. C. Stewart, op. cit., p. 66. 
CHAPTER IV

\section{RESULTS AND DISCUSSION}

The null hypotheses tested in the present research included the following three:

1) There is no similarity between the value system of the Japanese male college students and that of American male college students whose ages are between 18 and 22 .

2) There is no similarity between the value system of Japanese female college students and that of American female college students whose ages are between 18 and 22 .

3) There is no similarity between the value system of the Japanese college students (male and female) and that of the American college students (male and female) whose ages are between 18 and 22 .

The spearman rank order correlation coefficient (Rho) was computed for each of the null hypotheses. An orthogonal factor analysis was done on the Harris 220 at the PSU computer center.

In this chapter the results and discussion for each null hypothesis will be presented first, followed by comment on comparison of male and female results in each culture. Then the findings from the factor analysis will be presented.

Hypothes is 1

The rank order correlation coefficient obtained for the Japanese and American male students is .52 which is 
sufficiently high to reject the first null hypothesis since the critical value at the level of significance, $\alpha=.05$ and $\mathrm{N}=15$ is .46. It is likely that the Japanese male students and the American male students in this study have a similar value system.

The average ranks of each value and rank differences between the two groups' rankings are presented in Table III below.

\section{TABLE III}

AVERAGE RANKS AND DIFFERENCES--MALE

\begin{tabular}{lrrr}
\hline & \multicolumn{2}{c}{ Group } & Mean \\
\cline { 2 - 3 } Value & Jap. & Amer. & Differ. \\
\hline Deep understanding of the world & 5.66 & 9.95 & -4.29 \\
Diligence--hard-working & 8.19 & 9.42 & -1.23 \\
Family unity & 5.85 & 7.93 & -2.08 \\
Fulfillment of obligation \& duty & 8.28 & 7.82 & 0.46 \\
Group loyalty & 12.19 & 10.80 & 1.39 \\
Group success & 10.34 & 11.16 & -0.82 \\
Human equality & 7.62 & 8.09 & -0.47 \\
Independence & 5.79 & 7.02 & -1.23 \\
Individual achievement & 8.66 & 6.78 & 1.88 \\
Inner harmony & 7.25 & 5.22 & 2.03 \\
Personal happiness & 6.07 & 3.40 & 2.67 \\
Respect for others & 8.11 & 7.18 & 0.93 \\
Self-respect & 7.70 & 5.13 & 2.57 \\
Social status & 10.30 & 11.27 & -0.97 \\
A world of beauty & 8.40 & 10.44 & -2.04 \\
\hline
\end{tabular}


"Deep understanding of the world," "Personal happiness," and "Self-respect" show a rather noticeable difference in each group's response, but an overall similarity in rankings is apparent. The similarity becomes more apparent when the first five choices for each group are compared. Table IV shows the five highest-ranked values in each culture with their average ranks.

\section{TABLE IV}

TOP FIVE VALUES WITH THEIR AVERAGE RANKS--MALES

Japanese

rank

American

rank

1. Deep understanding 5.66 Personal happiness 3.40

2 Independence

5.79 Self-respect

5.13

3 Family unity

5.85 Inner harmony

5.22

4 Personal happiness

6.07 Indiv. achievement

6.78

5 Inner harmony

7.25

Independence

7.02

Note that. "Personal happiness" is dominant among the American male students' response and also that three other values such as "Self-respect," "Individual achievement," and "Independence" which are all connected with individualism are included in the top five values. "Inner harmony" which is ranked the third-highest could be an indication of the American youth's further contact with Eastern philosophies. In regard to the Japanese top five values, the firstranked "Deep understanding of the world" clearly separates 
the Japanese response from the American one and seems to indicate a need to learn more about the world and possible themselves.

Despite the above-mentioned differences between the groups, the Japanese and the American first five values present a striking similarity as they share three values, namely "Independence," "Inner harmony," and "Personal happiness." Edward Norbeck's observation in 1964 which recognized a new attitude toward happiness seems to have gained more ground among the Japanese youth today. At the same time, it should be pointed out that Japanese traditional values such as "Diligence," "Fulfillment of obligation and duty," "Group loyalty," "Group success," and "Respect for others" are not included among the top five values by the Japanese.

\section{Hypothes is 2}

The rank order correlation coefficient for the American and Japanese female students is .41. It is lower than .52 for the male students' correlation, but still high enough to reject the null hypothesis at $p<.10$. Therefore, it is also likely that the American and Japanese female students share a similar value system.

The average ranks for each value and differences between the two groups' rankings are presented in Table $\mathrm{V}$ on the next page.

In the male response, "Deep understanding of the world" showed the largest difference, but the female's rankings 
TABLE V

AVERAGE RANKS AND DIFFERENCES--FEMALE

\begin{tabular}{lrrr}
\hline & \multicolumn{2}{c}{ Group } & Mean \\
\cline { 2 - 3 } Value & Jap. & Amer. & Differ. \\
\hline Deep understanding of the world & 3.94 & 11.70 & -7.76 \\
Diligence--hard-working & 7.16 & 9.61 & -2.45 \\
Family unity & 6.06 & 5.44 & 0.62 \\
Fulfillment of obligation \& duty & 9.71 & 5.61 & 4.10 \\
Group loyalty & 12.91 & 11.10 & 1.81 \\
Group success & 11.13 & 12.05 & -0.92 \\
Human equality & 5.68 & 8.02 & -2.34 \\
Independence & 3.90 & 6.28 & -2.38 \\
Individual achievement & 10.19 & 6.49 & 3.70 \\
Inner harmony & 4.84 & 4.28 & 0.56 \\
Personal happiness & 6.79 & 4.69 & 2.10 \\
Respect for others & 7.71 & 6.38 & 1.33 \\
Self-respect & 8.29 & 3.61 & 4.68 \\
Social status & 11.66 & 12.48 & -0.82 \\
A world of beauty & 8.99 & 11.15 & -2.16 \\
\hline
\end{tabular}

present a more extreme result, with a value difference of 7.76. The Japanese female students chose "Deep understanding of the world" as the second most important value with the average rank of 3.94 while the American counterparts ranked it thirteenth with an average rank of 11.70. "Fulfillment of obligation and duty" also shows a significant gap in each group's response. It is possible that its low ranking among the Japanese subjects is connected with the Japanese word ("Gili-Ninjoh") used in the Japanese version of the present 
value list, which has a strong negative flavor as a traditional value.,

Another aspect of the Japanese female rankings is that "Independence" is chosen as the most important value. This seems to indicate the Japanese female college students' strong concern about being independent and their clear separation from the traditional stereotype of Japanese women. An underlying similarity between the Japanese and American female students is found in their five most highly ranked values. Table VI below shows the first five values chosen by the female subjects.

TABLE VI

TOP FIVE VALUES WITH THEIR AVERAGE RANKS--FEMALE

Japanese rank American rank

1 Independence

3.90 Self-respect

3.61

2 Deep understanding

3.94 Inner harmony

4.28

3 Inner harmony

4.84 Personal happiness

4.69

4 Human equality

5.68 Family unity

5.44

5 Family unity

6.06 Fulfillment

5.61

"Self-respect" is a dominant value among the American female students while the Japanese chose "Independence" for the first place. "Self-respect" and "Independence" are quite different in their descriptive meanings, but an underlying feeling which made both cultural groups choose their 
respective answer seems to be the same, i.e., strong concern about "self" and identity among women.

Again "Inner harmony" is shared by the both groups as it was among the male students, but it is interesting to find that "Family unity" is shared only by the females.

\section{Hypothesis 3}

The rank order correlation coefficient for the total subjects (male and female) of the two cultures is .51, which is slightly lower than that of the male subjects, but still high enough to reject the null hypothesis. Along with the results of the first and second hypotheses, the third null hypothesis of the present research is accepted. In other words, there is a high positive relationship between the value system of the Japanese college students and that of the American students.

Combining the data from males and females results in a similar value system for the two cultures. Table VII on the next page shows the differences in each group's responses. only four values present a noticeable difference in rankings. "Deep understanding of the world," "Individual achievement," "Self-respect," and "A world of beauty" recorded an average rank difference more than 2.00. The rest of eleven values are ranked almost identically by both cultural groups.

It seems like the West is approaching the East and at the same time the East is approaching the West. The Japanese students ranked such western values as "Independence" and 
TABLE VII

AVERAGE RANKS AND DIFFERENCES--MALE AND FEMALE

Value

Jap. Amer. Differ.

Deep understanding of the world

5.13

10.40

$-5.27$

Diligence-hard-working

7.87

3.52

$-0.65$

Family unity

5.92

7.15

$-1.23$

Fulfillment of obligation \& duty

8.73

7.18

1.55

Group loyalty

12.42

10.96

1.46

Group success

10.58

11.63

$-1.05$

Human equality

7.01

8.05

$-1.04$

Independence

5.21

6.63

$-1.42$

Individual achievement

9.14

6.63

2.51

Inner harmony

6.50

4.72

1.78

Personal happiness

5.29

4.08

1.21

Respect for others

7.98

6.76

1.22

Self-respect

7.89

4.33

3.56

Social status

A world of beauty

10.73

11.91

$-1.18$

8.58

10.81

$-2.23$

"Personal happiness" among the first five and such traditional values as "Group loyalty," "Group success," and "Social status" low. On the other hand, the American students ranked a traditionally eastern value, "Inner harmony" in third place and a wester "Human equality" rather low, while keeping values such as "Personal happiness," "Self-respect," "Independence," and "Individual achievement" in the top group.

Table VIII shows the five most important values selected by all the Japanese and American subjects. 
TABLE VIII

TOP FIVE VALUES WITH THEIR AVERAGE RANKS--MALE AND FEMALE

Japanese

rank

Amèrican

rank

1 Deep understanding

5.13

Personal happiness

4.08

2 Independence

5.21

Self-respect

4.33

3 Personal happiness

5.29

Inner harmony

4.72

4 Family unity

5.92

Independence

6.63

5 Inner harmony

6.50

Individual achieve.

6.63

Possible explanations for the similarities are many and a. single cause cannot be determined with ease. Several will be considered here.

The postwar education in Japan which fostered individualism and democracy must definitely be a factor in shaping the value system of the young people referred as "Sengo" in the first chapter. Educational emphasis on individual achievement and growth seems to have had a diminishing effect on such traditional values as "Fulfillment of obligation and duty," "Group loyalty," and "Group success" while it encouraged a growth of such values as "Independence" and "Personal happiness."

The great influx of American popular cultures represented by T-shirts, jeans, music, movies and TV programs may also be a factor. Importing the trappings of a culture does not mean transmittence of the deeper cultural values and 
thought patterns, but the initial adoption of elements of the American culture by the Japanese as represented by the wearing of T-shirts and jeans could have led to adoption of American values. Outward forms of the other culture, i.e., concrete objects or artifacts such as T-shirts seem to function as a trigger for a further cultural transformation which includes value change.

Besides the above-mentioned two explanations, another possible cause has been identified in the loss of the parents' role as a value transmitter in postwar Japan as William Caudill suggested. The decline of Japanese parents' ("Senchu" generation) authority and power after the war seems to have been of sufficient magnitude to cause failure of value transmittence.

The change in the values of American youth is also of interest. One explanation could be that young people in America have been more exposed to Eastern philosophies and ideas during the '60s and could therefore have attained a new profile which would separate them from their parents. Furthermore, the upsetting circumstances of the Vietnam war and Watergate could have caused the American youth to question their traditional values such as "Diligence" and "Social status" which were ranked low by the American subjects. 
Within-culture Analysis

Japanese males and females. Among the first five values chosen by the Japanese males and females, four are shared by both sexes. According to Tables IV and VI, "Deep understanding of the world" and "Independence" occupy the first and second place in the rankings by each sex. "Family unity" and "Inner harmony" are also included in each group. Japanese males and females show a remarkably similar outlook in their value systems.

One of the differences in the ranking of the top five is that the order differs. For example, Japanese males placed "Personal happiness" fourth whereas the females ranked "Human equality" fourth. But when we take into account the fact that "Personal happiness" was ranked sixth by females and "Human equality" was also sixth by males, the difference could be said to be minimal.

American males and females. The American male and female students both share the first three values they thought most important, but the male included "Individual achievement" and "Independence" for the fourth and fifth, while the female had "Family unity" and "Fulfillment of obligation and duty" fourth and fifth.

Interesting difference is found in "Personal happiness" and "Self-respect." The female students ranked "Selfrespect" first with the average rank value 3.61 , while the male students put it second, with an average rank value of 5.13. It seems safe to say that the American female 
students' concern over self-respect is relatively stronger for them than for the male students. Since we have only ranked data, we cannot determine whether females or males have stronger concerns with respect to these values.

In regard to "Personal happiness," the males ranked it at 3.40 while the females placed it at 4.69 .

\section{Factor Analysis}

Table IX on the next page shows the correlation matrix for the fifteen values in the Japanese response.

Among other things, fairly high positive correlations were found among the following:

1) Deep understanding of the world and Inner harmony $(r=.52)$

2) Group loyalty and Group success $(r=.68)$

3) Independence and Deep understanding ( $r=.52)$

4) Individual achievement and Personal happiness, Social status $(r=.54, .81)$

It should be noted that "Group loyalty" and "Group success" were ranked quite low by the Japanese students. It seems to indicate the Japanese students' detachment from these two traditional values.

Fairly high negative correlations were found between the following pairs values:

1) Deep understanding and Social status $(r=-.65)$

2) Diligence and Personal happiness $(r=-.65)$

On the other hand, the correlation matrix for the American's values (Table X) indicated fairly high positive 
ONONW

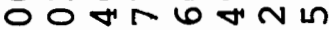

$\infty$

0 in $m+0$ in $\mathrm{H}$ o

o o $N \infty$ on 6 or

ด ก ก -

o $\infty$ a 0 an O $60 \mathrm{~m}$ a $\mathrm{N}$ a

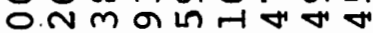

$N$ $0 m N m m \circ m \infty \Gamma$ ONmoमfनH० í $\dot{0} 0 \dot{0} \dot{0} 0 \dot{0}$

$$
0_{1}^{0} 0_{1} 0_{1} 0_{1} 0_{1}
$$

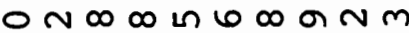
omo n $\mathrm{N}$ in

6 $00 \forall m N$ N $N m+\infty$ $00 \mathrm{~m} N \mathrm{NO}$ in ON MONONOOO - 000000000000

$00 \pi m 0 N \pi \infty$ n $00 \mathrm{~N} 00$ in $160 \infty \infty$

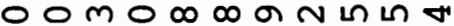

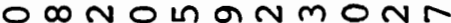
0 . 0 N MN MOONO - $\dot{0} \dot{0} \dot{0} \dot{0} \dot{0} \dot{0} \dot{0}$ $-1000000000000$

O $0 \sim$ a $N \infty \forall \forall$ 0 4 $0+\infty 6 \pi N \mathrm{~N} m \omega$ in 00 Oठ í $\dot{0} \dot{0} \dot{0} \dot{0} \dot{0} \dot{0} \dot{0} \dot{0} 0$

$$
\text { न } 100000000000
$$

OHON $0 \infty \pi N \infty$ ॠ

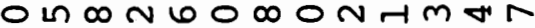

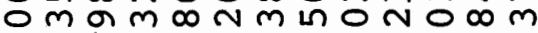
$000 \mathrm{NOOHHONO} 0 \mathrm{~m}$

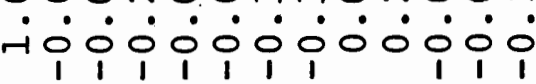

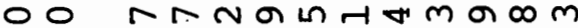

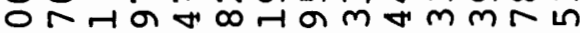
0 o $\infty$ म 0 ॠ ० न व० न N

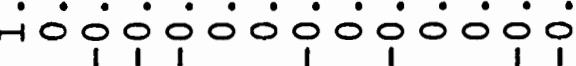

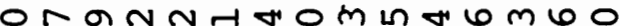

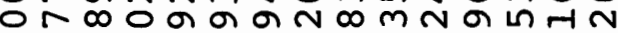
O

H ON 0 in $00 \mathrm{NOH} H \mathrm{~m}$ in in $\mathrm{mom} 6 \mathrm{~m}$

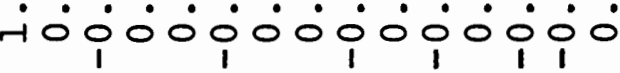

N

$m$

$\begin{array}{ll}0 & 0 \\ 1 & 0 \\ 0 & 0 \\ & -\end{array}$

$\stackrel{4}{\mathbb{4}}$

$0 \infty$

0

0

品

$\dot{10}$

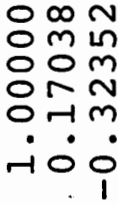

o 61

$00 \pi \infty$

$0 \infty \pi+$

$06 \pi$ in

ONON

म0ं

$O m$ v $m o$

Omon $\mathrm{m}$

न

ONOMr

- $\dot{0} \dot{0} \dot{0}$

11

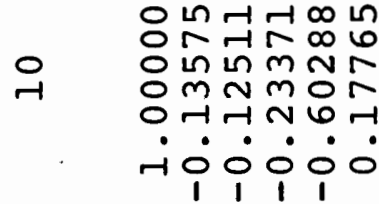

OกN $00 \mathrm{~m}$ a 6 त o in a o 1 in

$\sigma$ $0 \infty \forall$ in a 00 O $\mathrm{m} m \mathrm{~m} \infty 0$ नं 
$\infty$

N

6

in


Oma $060 \mathrm{~m}$ $0 \forall \forall m-1 \infty 0 m$ 000 in 00 an $0 \% N$ N 0 N $060 \mathrm{~m} / \mathrm{N}$ تं

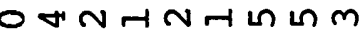
$0 N+\infty \cup \Gamma \infty m$ O $m \mathrm{~m}+\mathrm{N}$ H O $\infty \mathrm{m} \bullet \mathrm{H} \boldsymbol{\mathrm { N }}$ OON NON MON - $\dot{0} \dot{0} \dot{0} \dot{0} \dot{0} \dot{0}$

0 I 0 ( 0 \& ONom $0 \infty \sigma n m+N a$ O $N$ N N $N$ F -

omanNwo $06 N-m+1 \%$ $06 \mathrm{~m} N \mathrm{~N}$ 대 $\infty \mathrm{m}$. 00 HN H

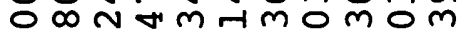
-100

○

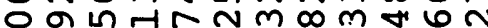

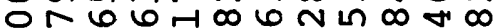

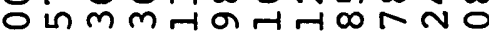

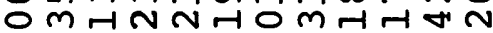
تं $0_{1} 0_{1} 00_{1}^{0} 0_{1}^{0} 0_{1}$

00 HN ONOL H 0 rmN $0 N \infty$ in $m m n M$ in $m$.

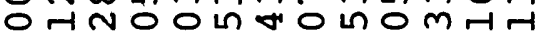
-

ONNmमO 0 in $\infty 66 \mathrm{~m}$ on $N$ O 0 in $\mathrm{m} 0$ \% O $\sigma$ I

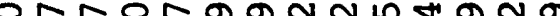

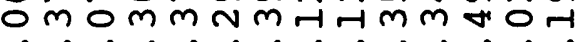
-i $\dot{0} \dot{0} \dot{0} \dot{0} \dot{0} \dot{0} \dot{0} \dot{0} \dot{0} \dot{0} \dot{0} 0$ $10_{1} 0_{1} 0_{1} 0_{1} 0_{1}$

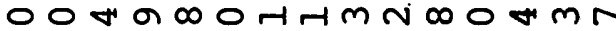
ONNN In $060 \forall 4 \infty \pi+1)$

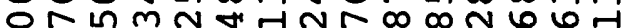
$0 \mathrm{~m} N 0000 \mathrm{~N} N \mathrm{~m}$ H $0 \mathrm{~N}$

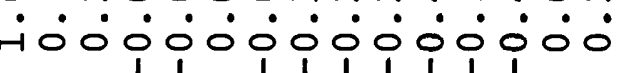

$\begin{array}{ll}11 & 0 \\ & 0 \\ & 0 \\ 0 & \\ & \end{array}$

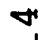

\begin{tabular}{cc}
0 & $m$ \\
0 & $N$ \\
0 & -1 \\
0 & 8 \\
0 & -1 \\
$ن$ & 0 \\
\hline & 0
\end{tabular}

0 ar

or 6

$m$

0 in

00 in

0 म

म 00

$0 \pi N \in$

On $6 \mathrm{~m}$

N $\quad 0 N \infty \infty$

O $m$ ON

$0 \mathrm{O} 0 \mathrm{O}$

मिं

$0 * m-\infty$ $0 m \infty \circ$

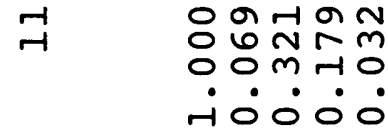

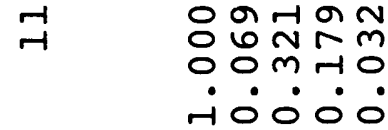

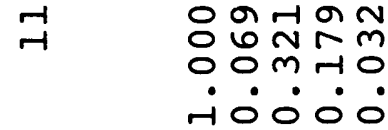

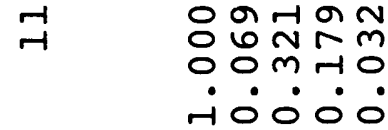

Oran a

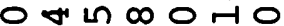
$0 \pi \pi n+\pi$ $000 \mathrm{~m} \mathrm{~mm}$ O $N$ N $00 \mathrm{H}$ - $\dot{0} \dot{0} \dot{0} \dot{0} \dot{0}$ म०० 0000 
correlations in the following value groups:

1) Group loyalty and Group success $(r=.81)$

2) Independence and Individual achievement $\quad(r=.66)$

Both "Group loyalty" and "Group success" were ranked low by the subjects while "Independence" and "Individual achievement" received the same average rank of 6.63 .

A significant negative correlation was found between two values, namely, "Family unity" and "Personal happiness" $(r=-.54)$.

Tables XI and XII are the rotated factor matrices for the Japanese and American values.

From the Japanese rotated factor matrix (Table XI), the following three factors were obtained:

Factor 1: High--Individual achievement Social status Unrelated--Deep understanding of the world Inner harmony

Factor 2: High--Group loyalty Group success Unrelated--Inner harmony

Factor 3: High--A world of beauty

From the American rotated factor matrix (Table XII), the following four factors were obtained:

Factor 1: High--Family unity Unrelated--Independence

Individual achievement

Factor 2: High--Group loyalty and Group success Unrelated-A $A$ world of beauty

Factor 3: High--Self-respect Unrelated--Deep understanding of the world Diligence 
TABLE XI

ROTATED FACTCR MATRIX--JAPANESE

Factor

Variable

1

2

3

\begin{tabular}{rrrr}
\hline 1 & -0.83361 & 0.05070 & 0.19297 \\
2 & -0.29361 & 0.05170 & -0.45514 \\
3 & 0.12353 & -0.11414 & -0.38164 \\
4 & -0.04020 & -0.07782 & -0.44821 \\
5 & -0.10264 & 0.91223 & -0.02563 \\
6 & 0.16943 & 0.77050 & 0.23396 \\
7 & -0.18273 & 0.02875 & -0.02082 \\
8 & -0.48773 & -0.25305 & -0.10940 \\
9 & 0.80520 & -0.28199 & 0.35455 \\
10 & -0.68846 & -0.36576 & 0.10729 \\
11 & 0.41451 & -0.28188 & 0.45566 \\
12 & -0.05881 & 0.01810 & -0.41436 \\
13 & 0.35193 & 0.05615 & -0.12516 \\
14 & 0.80138 & -0.10633 & 0.06907 \\
15 & -0.37211 & -0.03668 & 0.80057 \\
\hline
\end{tabular}

Factor 4: High--Social Status

Unrelated--Inner harmony

Interestingly, the Factor 2 in both cultures is almost identical.

For the Japanese, "A world of beauty" is one of three independent factors.

Among the American factors, Factor 3 and 4 reflect independent values. One can have one without the other. On the other hand, for the Japanese subjects, "Individual achievement" and "Social status" go together. 
TABLE XII

ROTATED FACTOR MATRIX--AMERICAN

\begin{tabular}{crrrr}
\hline & \multicolumn{4}{c}{ Factor } \\
Variable & 1 & \multicolumn{1}{c}{3} & \multicolumn{1}{c}{4} \\
& & & & \\
\hline 1 & 0.22227 & -0.31710 & -0.75552 & 0.23434 \\
2 & 0.12710 & 0.24462 & -0.61101 & 0.02902 \\
3 & 0.55500 & 0.00955 & -0.27039 & -0.12153 \\
4 & 0.25121 & 0.27117 & 0.03030 & -0.44475 \\
5 & 0.34953 & 0.77539 & -0.06306 & -0.01899 \\
6 & 0.08042 & 0.80460 & -0.16680 & 0.22364 \\
7 & 0.35402 & -0.46367 & 0.30289 & 0.12318 \\
8 & -0.70175 & -0.18673 & 0.03322 & -0.03237 \\
9 & -0.81671 & 0.03713 & -0.05156 & -0.06945 \\
10 & -0.18477 & -0.08859 & 0.04616 & -0.51474 \\
11 & -0.45798 & -0.02608 & 0.40660 & 0.11151 \\
12 & 0.36013 & -0.00387 & 0.54228 & -0.01216 \\
13 & -0.11766 & -0.05738 & 0.61184 & 0.11835 \\
14 & -0.10239 & 0.16543 & 0.04087 & 0.80887 \\
15 & 0.03427 & -0.56627 & -0.16233 & -0.03674 \\
\hline Eigenvalue & 3.44790 & 1.65748 & 1.49017 & 1.26630 \\
\hline
\end{tabular}




\section{SUMMARY AND CONCLUSION}

The present research attempted to investigate the possible similarity between the value system of the Japanese college students and that of the American college students whose ages ranged from 18 to 22 .

Three null hypotheses were set up. The first null hypothesis was to test the similarity of values among the male students and the second null hypothesis was to test the similarity among the female students. The third one was intended to test the similarity of values among the total (male and female) students.

To test the hypotheses, a list of values was constructed by the writer. The value list consisted of the following Japanese and American values:

1) Deep understanding of the world

2) Diligence--Hard working

3) Family unity

4) Fulfillment of obligation and duty among your friends and relatives

5) Group loyalty

6) Group success

7) Human equality

8) Independence

9) Individual achievement

10) Inner harmony

11) Personal happiness

12) Respect for others

13) Self-respect

14) Social status

15) A world of beauty 
The Iist and procedure were designed to measure a fairly wide area of the individual's value system and its hierarchical structure.

The value list was administered to 219 Japanese college students at three universities in Tokyo and 115 American college students in Portland, Oregon.

The results revealed that the Japanese and American college students in Tokyo and Portland share a similar value system and structure. Correlation coefficient for each null hypothesis showed a positive relationship and as a result, all of the hypotheses were rejected. Consequently, the research hypothesis of the present research which stated that there is a positive relationship between the values system of the Japanese college students and that of the American students was accepted. The Japanese and American youth today seem to be much closer to each other in their value system than their predecessors in their respective countries.

Edward Norbeck (1) and Robert Lifton (2) observed sharply changing values among the Japanese youth in the '60s. Later, Arkoff, Berrien, and Iwahara (3) presented the generation differences in values among the Americans, Japanese-Americans, and Japanese and at the same time pointed out that the Japanese and Japanese-American sons are more like each other than they are like their fathers. These findings by different scholars in the ' 60 s seem to be confirmed and magnified in the present research. 
Table VII in the previous chapter well illustrates a remarkable similarity in each value's average rank. Only four values such as "Deep understanding of the world," "Individual achievement," "Self-respect," and "A world of beauty" present a noticeable difference in rankings. The other eleven values' average ranks are almost identical.

It has been several decades since Ruth Benedict (4) described marked differences between the Japanese culture and the Western culture. Also the people who followed her footstep have been primarily concerned with the description of the uniqueness of the Japanese culture. However, the results of this research seem to indicate that a consistent change toward similarity in values among the Japanese and American youth has been in progress while most of the past studies were concerned with finding differences:

Final words regarding the further application of the present research should be added. It is the opinion of the writer that application of the present value list to the Japanese and American middle-age group should be an interesting study to check the validity of the writer's value list and also to investigate the generational differences of the value system, if any, in the two countries. 
${ }^{1}$ Edward Norbeck, Changing Japan (New York: Holt, Rinehart and Winston, 1965), p. 21 .

2 Robert Lifton, "Youth and History: Individual Change in Postwar Japan," in The Challenge of Youth edited by Erik H. Erikson (New York: Doubleday, 1965), p. 270.

3 Abe Arkoff, Frank Berrien, and Shinkuro Iwahara, "Generation Differences in Values: American, JapaneseAmerican, and Japanese," Journal of Social Psychology, 1967, $71,169-175$.

${ }^{4}$ Ruth Benedict, The Chrysanthemum and the Sword (London: Routledge \& Kegan Paul Ltd., 1967), p. 116. 


\section{BIBLIOGRAPHY}

Adler, Franz 1956. "The Value Concept in Sociology," American Sociological Review, 62, 272-279.

Albert, Ethel 1968. "Value Systems," in The International Encylopedia of the Social Sciences, pp. 287-91. New York: Macmillan.

Anastasi, Ann 1976. Psychological Testing (4th ed.), New York: Macmillan.

Benedict, Ruth 1967. The Chrysanthemum and the Sword, London: Routledge \& Kegan Ltd:

Berrien, Frank K., Arkoff, Abe and Iwahara, Shinkuro 1967. "Generational Difference in Values: American, Japanese-American, and Japanese," Journal of Social Psychology, 71, 169-175.

Berrien, Frank K. 1966. "Japanese and American Values," International Journal of Psychology, Vol. 1, No. 2, $\overline{129-141 .}$

Berrien, Frank K. 1968. "Cross-cultural Equivalence of Personality Measures," Journal of Social Psychology, $75,3-9$.

Caudill, William 1961. "Around the Clock Care in Japanese Psychiatric Hospital," American Sociological Review, $26,204-214$.

Caudill, William and Scarr, Harry 1962. "Japanese Value Orientation and Culture Change," Ethnology, Vol. 1, No. $1,53-91$.

Condon, John and Yousef, Fathi 1976. An Introduction to Intercultural Communication, Indianapolis: BobbsMerril.

Doi, Takeo 1971. Structure of Dependence, Tokyo: Kodansha International.

Dore, R. P. 1958. City Life in Japan, Berkeley: University of California Press.

Dore, R. P. 1969. "The Japanese Personality," in Asia Handbook edited by Guy Wint, Harmondsworth: Penguin Books. 
Gibney, Frank 1975. Japan: The Fragile Superpower, Tokyo: C. E. Tuttle.

Glass, Gene 1972. "Review on the Survey of Personal Values" in the Seventh Mental Measurement Yearbook edited by O. K. Buros, New Jersey: Gryphon Press.

Goodman, M. E. 1957. "Values, attitude and social concepts of Japanese and American children," American Anthropologist, 59, 979-989.

Gordon, Leonard V. and Kikuchi, Akio 1966. "American Personality Tests in Cross-cultural Research - A Caution," Journal of Social Psychology, 69, 179-183.

1970. "Japanese and American Personal Values," International Journal of Psychology, Vol. 5, No. 3, 183-187.

Gordon, Leonard V. 1968. "Comments on Cross-cultural Equivalence of Personality Measures," Journal of Social Psychology, 75, 11-19.

Hogan, Robert 1972. Review on the study of Values," in The Seventh Mental Measurement Yearbook edited by $0 . k$ : Buros, New Jerseỹ: Gryphon Press.

Kahn, Herman 1973. The Emerging Japanese Superstate, Harmondsworth: penguin Books.

Klapper, Joseph 1960. The Effect of Mass Communication, New New York: Free Press.

Kluckhohn, Clyde 1951. "Values and Value Orientation in the Theory of Action," in Toward a General Theory of Action edited by Talcott Parsons and Edward Shils, Cambridge: Harvard University Press.

Kluckhohn, Florence and Strodtbeck, Fred 1961. Variations in Value Orientations, Evanston: Row, Peterson.

Lifton; Robert 1965." "Youth and History: Individual Change in Postwar Japan," in The Challenge of Youth edited by Erik. H. Erikson, New York: Doubleday.

Morris, Charles 1956. Varieties of Human Values, Chicago: University of Chicago Press.

Nakane, Chie 1972. Japanese Society, Berkeley: University of California Press.

Norbeck, Edward 1965. Changing Japan, New York: Holt, Rinehart, and winston. 
Rokeach, Milton 1972. Beliefs, Attitudes and Values, San Francisco: Jassey-Bass.

1973. The Nature of Human Values, New York: Free Press.

Scott, William A. 1965. Values and Organization: A study of Fraternities and Sororities, Chicago: Rand McNally.

Sengoku, Tamotsu and Toyama, Atsuko 1973. Hikaku Nihonjinlon (World Youth Survey), Tokyo: Shogakukan.

Stewart, E. C. 1971. American Cultural Patterns, Pittsburgh: Regional Council for International Education.

Triandis, Harry 1972. The Analysis of Subjective Culture New York: John wiley.

Triandis, Harry, Shanmugan, A. V. and Tanaka, Yasumasa 1966. "Interpersonal Attitudes Among American, Indian and Japanese Students," International Journal of Psychology, $1,177-206$.

Van Zandt, Howard 1976. "How to negotiate in Japan," in International Communication: A Reader, by Larry A. Samovar and Richard E. Porter, Belmont, CA: Wadsworth Publishing.

Wallace, Anthony 1961. Culture and Personality, New York: Random House.

Yanaga, Chitose 1956. Japanese People and Politics, New York: John Wiley. 


\section{APPENDIX D.}

Age

Sex :

Major:

Below is a list of 15 values arranged in alphabetical order. Your task is to arrange them in order of their importance to you as guiding principles in your life.

Study the list carefully. Then place a 1 next to the value which is most important to YOU. Place a 2 next to the value which is second most important to you, etc.

Work slowly and think carefully. If you change your mind, feel free to change your answer. The end results should truly show how You really feel.

Deep understanding of the world

Diligence--hard working

Family unity

Fulfillment of obligation and duty among your friends and relatives

Group loyalty

Group success

Human equality

Independence

Individual achievement

Inner harmony

Personal happiness

Respect for others--avoiding friction with other people

Self-respect

Social status

A world of beauty

Thank you! 
APPENDIX B

日米洒值钼了ンケート

年令:

性别. 男. 女票攻:

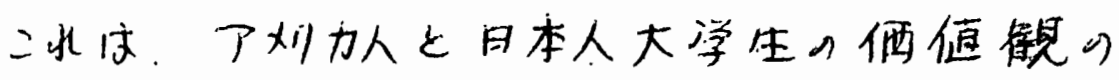
比敕調查を目的をするケンケー人です。

下記の159洒值を。立左たの人生に於师了重要性に 徒って䝨番をつリて下さ川。

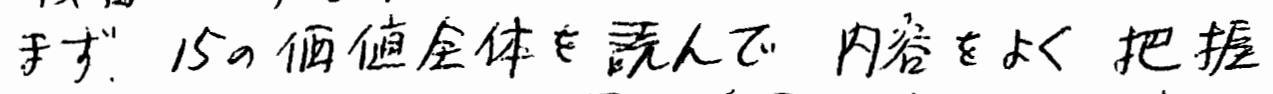

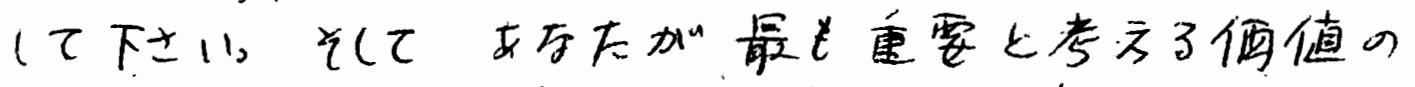

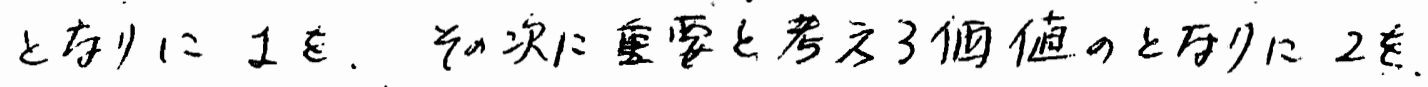
次下 15まで番号を要いて下さい。

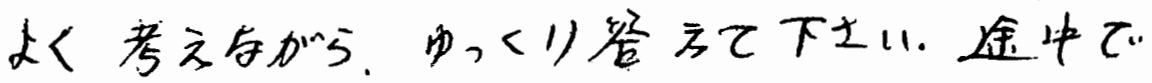

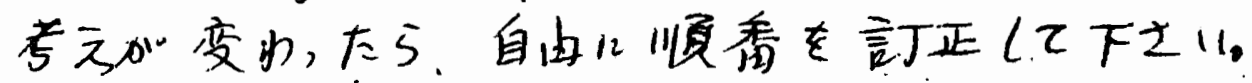

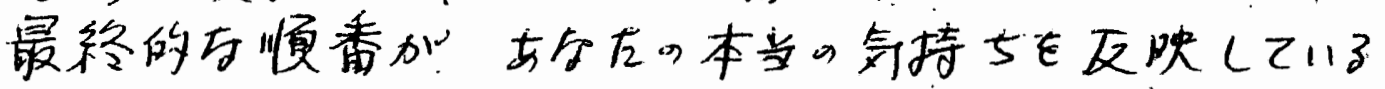
事が最光重要です。

家族内口調和

勤免西

義理人愲

ブループをはての成功

個人の幸福

自竓心

自立性(独上心)

ブルーブ第け主哉ーブループを(） 学11考方了

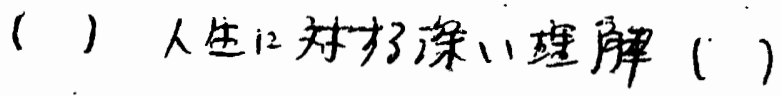

(1)社会的地位

( ) 個人a成功

（）他人林接敬一他人民。

库㨸・斌立を避け了(）

（）調和のと北左美(1地是（）

宇等

内面㖣和 